\title{
Descrição de duas espécies novas de Taperinha Linnavuori, 1959 (Homoptera, Cicadellidae, Deltocephalinae) ${ }^{1}$
}

Keti Maria Rocha Zanol ${ }^{2}$

\begin{abstract}
Two new species of Taperinha Linnavuori are described: T. maculata and T. excavata, from Peru and Guiana respectively.
\end{abstract}

Taperinha maculata sp. n.

(Figs 1-5)

Holotipo macho. Cabeça, em vista dorsal, mais longa medianamente, mais larga que o pronoto. Região frontal levemente elevada com microesculturações. Ocelos grandes, situados na margem anterior, perto dos olhos, visíveis de cima. Área ocelo-ocular estreita, aproximadamente cinco vezes menor que o diâmetro dos ocelos. Sutura coronal longa, ultrapassando a metade do vértice. Coloração geral amarelo-pálida com seis manchas, sendo: quatro alaranjadas, duas maiores sobre o disco de contorno irregular e duas na margem anterior, medianas, e duas junto aos ocelos, marrons. Face mais ou menos achatada e de coloração marrom. Genas com bordos sinuosos e uma reentrância abaixo dos olhos. Frontoclípeo levemente túmido. Anteclípeo mais largo apicalmente. Pronoto convexo, superfície lisa de coloração amarela com manchas irregulares sobre o disco e na margem anterior, amarelo-ouro. Escutelo com triângulos basais e uma mancha abaixo da sutura, amarelo-ouro; seis manchas arredondadas: duas sobre o disco e duas, de cada lado, nas margens, marrons. Tegminas claras, semitransparentes, com três células anteapicais. Veias extranumerárias na margem costal, nas células anteapical central e interna e no clavo. Coloração geral esbranquiçada com uma grande mancha mais ou menos triangular com sua base na margem anal e o ápice na altura da segunda célula discal, mancha esta formada por pontos marromescuros e esparsos, coalescentes nos bordos e duas pequenas áreas arredondadas, destituidas de pontos, junto à margem anal; margem costal com triângulos marrons; célula anteapical central e interna, pontuadas de marrom; terceira, quarta e quinta células apicais marrom-claras. Fórmula setal das tíbias anteriores

${ }^{1}$ Contribuição no. 627 do Departamento de Zoologia da Universidade Federal do Paraná.

${ }^{2}$ Centro de Identificação de Insetos Fitófagos da Universidade Federal do Paraná. CP.19030, 81504 Curitiba, Paraná, Brasil. 
$1+4$ e dos fêmures posteriores $2+2+1$. Valva triangular. Placas subgenitais triangulares. Pigóforo com um par de apêndices ventrais, de cada lado, partindo um próximo do outro, voltados para trás: o in terno mais delgado, de largura mais ou menos uniforme, levemente curvo, mais ou menos achatado, com ápice truncado e o externo mais achatado, a metade basal mais larga e estreitando-se apicalmente, serreada na margem superior e pontiaguda. Estilos robustos; apofise curvada para fora, bilobada apicalmente com o lobo externo mais longo e estreito. Edeado simétrico, tubular, pouco mais curto que o conetivo, levemente curvo para cima, com ápice bífido.

Medidas (em mm). Macho. Comprimento total 4,00; Largura da cabeça 1,32; Largura do pronoto 1,22 .

Holótipo macho de "Peru, San Jorge, 40mi W. Pucallpa $300 \mathrm{~m}$, X.4.54, E. I. Schlinger \& E. S. Ross collectors", depositado na coleção da California Academy of Science, California, USA.

Taperinha excavata sp.n.

(Figs 6-11)

Holótipo fêmea. Cabeça com seis manchas sendo duas alaranjadas, sobre o disco e quatro marrons, duas junto aos ocelos e duas medianas, na margem anterior. Escutelo com mancha alaranjada, logo após a sutura. Placa subgenital com fenda mediana larga e profunda, não atingindo a metade da placa; margens laterais à fenda levemente sinuosa.

Macho. Valva triangular. Placas subgenitais triangulares. Pigóforo com um par de apêndices ventrais, de cada lado, levemente curvos, voltados para trás e pontiagudos; o interno mais ou menos reto e delgado e o externo com ápice voltado para baixo. Estilos com apófise digitiforme, levemente curva para fora, com ápice truncado, fracamente bilobado. Edeago simétrico, tubular, levemente curvo para cima, com ápice bífido; superfície ventral com pequenas protuberâncias.

Medidas (em mm). Macho/fêmea. Comprimento total 4,20/4,40; Largura da cabeça $1,32 / 1,32$; Largura do pronoto $1,22 / 1,38$.

Holótipo fêmea de "Bri. Guiana, confluence of Orenoque e New Rivers 650ft 15 I.1938. Brit. Mus 1938-319". Parátipos: 1 fêmea da mesma localidade e data; 1 macho de "British Guiana Essequibo R. Moraballi Creek. 27.IX.1929 Oxf. Univ. Expdn BM 1929-485" e 1 macho de "Guyana, Courantyne RV Frederick William IV Falls C. A. Hutson III. 1936. BM 1978-55". Holótipo e um

FIGS. 1-5: Taperinha maculata sp. n. (Holótipo): 1, Cabeça e pronoto, vista dorsal; 2 , Tégmina; 3-5, Genitália do macho: 3, Edeago e conetivo, vista lateral; 4, Estilo; 5 , Pigóforo, vista lateral.

FIGS: 6-11: Taperinha excavata sp. n. 6, Cabeça e pronoto, vista dorsal (Holótipo); 7, Placa subgenital da fêmea (Holótipo); 8-11, Genitália do macho: 8, Pigóforo, vista lateral; 9, Estilo; 10, Edeago e conetivo, vista lateral; 11, Edeago, vista ventral. 
Vol. 6(2), 1989
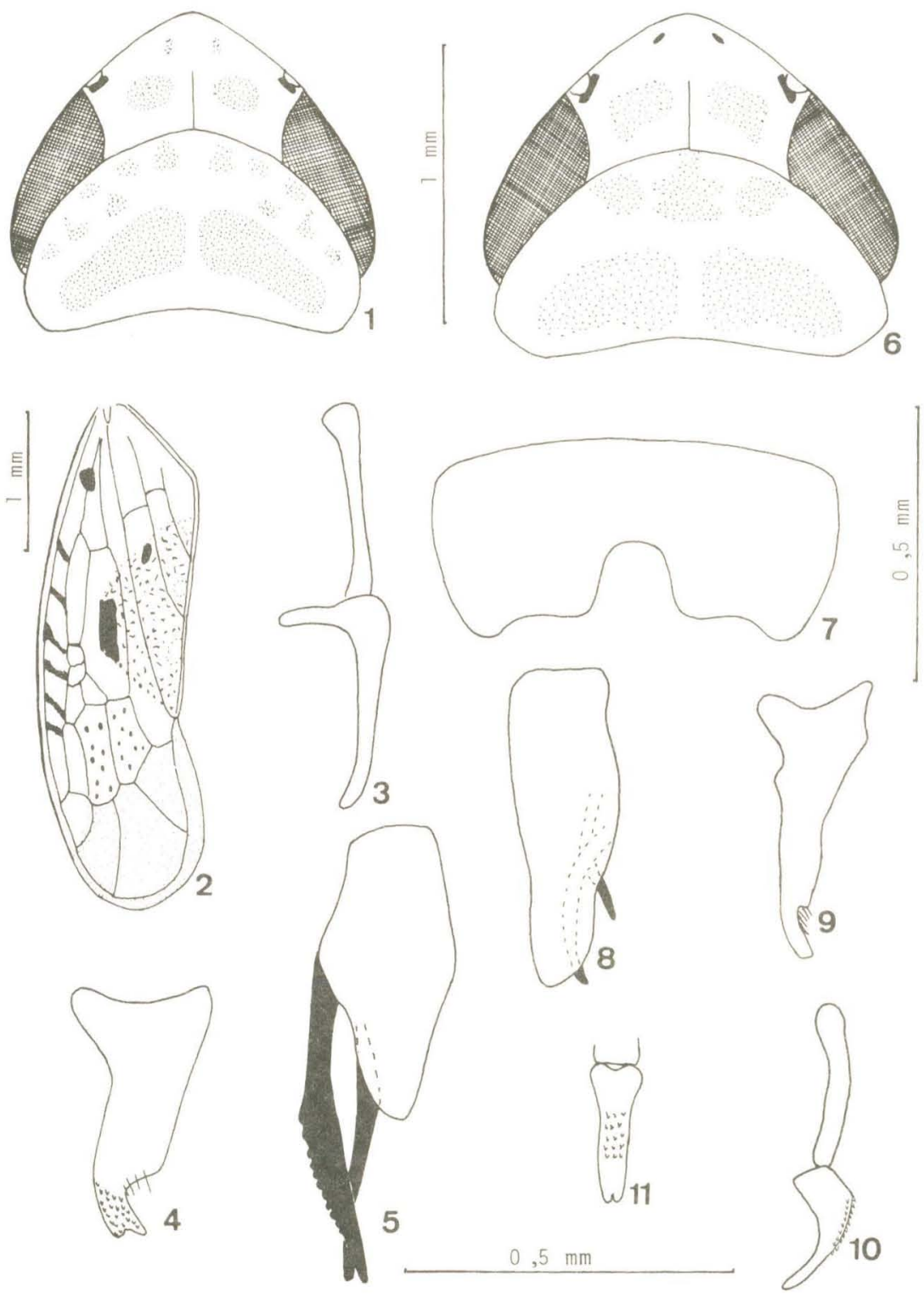
Revta bras. Zool.

parátipo macho depositados no British Museum (Natural History), Londres e demais parátipos na coleção do Museu Pe. Jesus Santiago Moure do Departamento de Zoologia da Universidade Federal do Paraná.

Discussão: Muito semelhante à especie anterior, diferindo na coloração geral e aspectos da genitália. 